\title{
DOKUMENTŲ APYVARTOS POKYČIAI SVEIKATOS PRIEŽIŪROS ORGANIZACIJOJE: ATVEJO ANALIZE்
}

\author{
Gaivilė Kasap ${ }^{1}$,Vinsas Janušonis ${ }^{1,2}$ \\ ${ }^{1}$ Klaipédos universitetinè ligonine, ${ }^{2}$ Klaipèdos universitetas
}

Raktažodžiai: dokumentų apyvarta, informacija, dokumentų srautai, dokumentų tvarkymas.

\begin{abstract}
Santrauka
Dokumentai sveikatos priežiūros organizacijoje (SPO), kaip informacijos šaltinis ir nešejas, yra labai svarbūs. Sveikata lemia gyvenimo kokybę ir trukmę, ji yra didžiausia žmogaus vertybė. Visko, kas susiję su žmogaus sveikata, jos priežiūra ir pokyčiais dokumentavimas yra ypač svarbus.

Darbo tikslas - apžvelgti dokumentų apyvartą ịvairių šalių sveikatos priežiūros organizacijose ir nustatyti popierinių dokumentų srautus bei jų pokyčius 2009, 2014, 2019 m. Klaipėdos universitetinèje ligoninèje.

Analizuotos ịvairių šalių mokslinès publikacijos, nagrinèjančios sveikatos priežiūros ịstaigų (ligoninių) dokumentų apyvartą, popierinių dokumentų srautus. Medžiaga sisteminta ir vertinta. Pateikta trumpa popierinių dokumentų apyvartos pokyčių analizė ligoninèje. Daroma išvada, kad popierinių dokumentų skaičius ir jų apyvarta Klaipèdos universitetinejje ligonineje yra dideli ir dar pamažu auga. Apibendrinant, galima teigti, kad dokumentų (popierinių ir elektroninių) pildymas, jų apyvarta, srautu valdymas, saugojimas yra labai svarbi sveikatos priežiūros organizacijos veiklos dalis. Ir medicinos, ir vadybos dokumentai yra svarbūs, gerinant sveikatos priežiūros kokybę.
\end{abstract}

\section{Ivadas}

Dokumentai sveikatos priežiūros organizacijoje (SPO), kaip informacijos šaltinis ir nešèjas, yra labai svarbūs. Sveikata lemia gyvenimo kokybę ir trukmę, ji yra didžiausia žmogaus vertybė. Visko, kas susiję su žmogaus sveikata, jos priežiūra ir pokyčiais dokumentavimas yra ypač svarbus.

Augant pacientų bei politikų reikalavimams, didejjant medicinos galimybėms gydyti sergančiuosius, gerejjant ligu prevencijos bei valdymo perspektyvoms, dideja ịvairių svei- katos priežiūros organizacijų dokumentų kiekis ir apimtis. Dokumentų srautai didejja ir dèl biurokratijos valstybès, sistemos, ịvairių žinybų ir organizacijų lygmenyse. Noras apie viską žinoti ne visada tikslingas ir naudingas, kartais netgi atvirkščiai - gali būti kenksmingas dèl konkurencijos, pacientų duomenų apsaugos neužtikrinimo ir kt. İvairių iššūkių ir problemų kelia neišvengiamas procesas - popierinių dokumentų keitimas elektroniniais ir jų valdymas.

SPO dokumentacija, ypač medicinine, tiesiogiai susijusi su sveikatos priežiūros kokybe - tai dar viena jos svarbos priežastis. Dokumentacijos apimtys, apyvarta bei srautai turi ir ekonominių aspektų, susijusių su tam tikrais kaštais, ženkliais organizacijai (gali didinti kaštus ar juos mažinti).

Darbo tikslas - apžvelgti dokumentų apyvartą įvairių šalių sveikatos priežiūros organizacijose ir nustatyti popierinių dokumentų srautus bei jų pokyčius 2009, 2014, 2019 $\mathrm{m}$. Klaipėdos universitetinejje ligoninèje.

\section{Tyrimo objektas ir metodika}

Tyrimas buvo vykdomas $2020 \mathrm{~m}$. sausio - rugsèjo mènesiais Klaipèdos universitetinejje ligoninejje.

Tyrimo objektas - popierinè dokumentacija įstaigoje.

Tyrimo metodai - retrospektyvine dokumentų apyvartos statistine ir lyginamoji analizè jos kaupimo objektuose (padaliniuose), literatūros analizè, duomenų sintezè ir apibendrinimas.

Analizuotos keturios dokumentų grupès: medicinos, vadybos, finansų ir kiti (įvairūs) dokumentai. Atlikta lyginamoji dokumentų apyvartos analizė ir jos pokyčiai 2009, 2014, 2019 metais. Kiti tyrimo metodai: mokslinès literatūros analizè ir sintezè, loginiai apibendrinimai ir išvados. Statistinei duomenų analizei atlikti buvo naudojama MS Excel programa ir statistikos programų paketas IBM SPSS 25.0. Taikyta aprašomoji statistika. Apskaičiuotas tyrimo duomenų dažnis (n), jo procentinè išraiška (proc.), vidurkis ir standartinis nuokrypis. Ryšiams nustatyti buvo naudojamas Spearman koreliacijos koeficientas (r) ir jo reikšmingumas (p). 


\section{Rezultatai ir jų aptarimas}

Dokumentacija sveikatos priežiūros organizacijose: trumpa literatūros apžvalga. Tinkamai sutvarkyta dokumentacija užtikrina sveikatos priežiūros tvarumą $[1,2]$. Dokumentai yra informacijos šaltinis ir nešejas, o informacija - sveikatos priežiūros valiuta [3]. SPO dokumentacija (popierinè ir e. laikmenoje) yra labai svarbi paciento sveikatos priežiūrai ir reikalinga nagrinèjant ịvairius teisinius klausimus. Dokumentacija suvokiama kaip ịrodymais pagrista informacija, o ne vieta, kurioje laikomi dokumentai, arba dokumentai, kuriems sukrauti reikalinga vieta. Kiekvienas dokumentas turi būti tikslingas (turèti apibrezžtą tikslą) ir būtinas, konkrečios paskirties, kuo labiau glaustas, atspindintis esmę, prieinamas, tvarkingas ir sukomplektuotas, atsekamas ir patikrinamas, lengvai skaitomas ir suprantamas, turiningas ir specifinis, ivykdomas ir kontroliuojamas.

Dauguma SPO dokumentacijos yra konfidenciali - paciento duomenys, jo sveikatos būklès įrašai, profesinè ir organizacijos informacija, todèl dokumentacija turi laiku pasiekti archyvus ar duomenų bazes, iš kurių gali būti paimama tik nustatyta tvarka. Dokumentacija sveikatos priežiūros ịstaigose gali būti standartinè (nustatyta ịvairių teisès aktų) ir nestandartinè. Neretai dokumentacija yra mišri ar iš dalies standartine (ligos istorijos, sveikatos istorijos ir kt.).

Dokumentai, kaip jau minèta, gali būti popieriniai ir elektroniniai. Nors popierinių dokumentų era baigiasi, tačiau jų dar daug naudojama ịvairių šalių sveikatos priežiūroje. Vien JAV sveikatos priežiūroje kasmet naudojama iki 2 milijardų klinikinių dokumentų, kurių dauguma buvo ir yra popieriniai [4].

Sveikatos priežiūros dokumentacijos srautai yra didžiuliai, jų apyvarta milžiniška, tačiau pacientai skundžiasi dokumentų nepakankamumu ir nekokybiškumu [5].

Nors ir pamažu nykstantys, popieriniai dokumentai turi savo privalumų: jie orginalūs, lengvai naudojami, laiku sudaromi, nepriklausomi nuo technologijų, jų kaštai mažesni, tačiau tokie dokumentai turi daug trūkumų - mažiau detalizuoti ir struktūrizuoti, gali būti neįskaitomi (rašyti ranka), sunkiau atgaminami praradus, sudètingesnè jų analizè, neefektyvi sklaida. Dèl popierinių, ypač ranka rašytų, dokumentu gali ịvykti medicinos klaidu, juos sunkiau administruoti bei naudoti. Išvengti klaidu padeda standartizuota dokumentacija [3,6]. Elektroniniai dokumentai, ypač dèl jų galimybiu , ,iškirpk“ ir ,,iterpk“ (angl. cut and paste), ,nukopijuok" (angl. copy forward), tapo mažiau aiškūs, kartais nepatikimi, neatspindintys vadybinès ir klinikinès situacijos $[7,8]$. Tokie dokumentai taip pat gali skatinti klaidų riziką, mažinti klinikinio mąstymo integralumą $[9,10]$. Esant didelei elektroninių dokumentų diegimo pažangai, 80 proc. medikų vis dar pasitiki popieriniais dokumentais [11].
SPO dokumentai pagal turini gali būti medicinos (klinikiniai), vadybos, mišrūs, kiti.

SPO dokumentacija pagal paskirti gali būti tarpžinybinè, sisteminè, organizacinè, struktūrinè, funkcinè.

Medicinos dokumentacija gali būti sudètinga (ligos istorija, sveikatos kortele, slaugos istorija ir kt.), bei nesudètinga [12]. Sudetinga dokumentacija, pvz. ligos istorija, jungia daugeli elementų. Tai paciento duomenys, medicinos darbuotojų įrašai, gydymo paskyrimas, laboratoriniai ir radiologiniai tyrimai, kiti duomenys. Medicinos dokumentacijai priklauso saugomi radiologiniai, ultragarsiniai ir kt. vaizdai, grafiniai vaizdai (elektrokardiogramos), garso įrašai, vaizdo įrašai (operacijų), klinikinių tyrimų medžiaga, moksliniai straipsniai ir pranešimai. Standartinių ar tikslių apibrěžimų, kas yra medicinos, klinikinis ar vadybos dokumentas, nèra. Kiekvienas dokumentas iš esmès yra orginalus ir dažniausiai mišrus. Iprastai medicinos (klinikinis) dokumentus kuria medikai, vadybos - ivvairaus rango vadybininkai. Beveik visi medicinos dokumentai rengiami daugelio autorių. Kuo labiau integruojama sveikatos priežiūra, tuo labiau integruojami medicinos ir kiti dokumentai $[13,14]$.

Tiek medicinos, tiek vadybos dokumentai turi glaudžias sąsajas su sveikatos priežiūros kokybe $[15,16]$. Dokumentų kokybè atspindi sveikatos priežiūros kokybę. Jie tampa be galo svarbūs epidemijų ar pandemijų metu (analizei realiu laiku) ir po jų. Dokumentuose registruojami faktai, véliau labai gelbstintys, kuriant prevencines kovos su epidemijomis priemones [17]. Tiksliai užpildyta ir išsaugota dokumentacija tampa pagrindiniu ịrodymų šaltiniu poepideminiais, pokriziniais laikotarpiais, kai šalyse keliamos bylos, kaltinami medikai, ligoninès [18].

Dokumentai yra ịvairūs - nuo laisvos formos tekstų iki struktūrinių ir interaktyvių. Jų kūrimui ir valdymui reikalingi ištekliai aprépia žmonių išteklius, laiko išteklius, kūrimo ir valdymo kaštus (finansiniai ištekliai), saugojimo ir naudojimo kaštus (finansiniai ištekliai).

Vadybos dokumentaciją sudaro vidaus teisès aktai (įsakymai, potvarkiai, tvarkos, protokolai ir kt.), susirašinejjimas su išorès korespondentais, ivvairūs audito ir kontrolès aktai, susirinkimų, pasitarimų, patariamujų organų susirinkimų protokolai, finansiniai, viešųų pirkimų, personalo dokumentai, planai, civilinès ir darbo saugos dokumentai, licencijavimo ir auditų dokumentai.

Mišriai (medicinos-vadybos) dokumentacijai priklauso nemažai ịvairių dokumentų - tvarkų, protokolų, pacientų srautų ir jų judejimo, pacientų registracijos ir kt.

Kita dokumentacija - tai valymo, skalbimo, mitybos, religinè ir kita dokumentacija.

Dokumentas yra sudètingas informacijos objektas, egzistuojantis nepriklausomai nuo naujų žinių. Sveikatos prie- 
žiūros dokumentas - ypač sudėtingas, jungiantis mokslo, klinikinės praktikos, ir vadybos žinias, daugeli žmonių grupių (medikus, pacientus, vadybininkus, politikus ir kitas), turintis aukštą konfidencialumo laipsni (žinios apie asmens sveikatą yra labai konfidencialios), apimantis daug smulkesnių dokumentų, tarp jų tekstinių, vaizdo, garso ir kitų.

Sveikatos priežiūros dokumentai atspindi sudètingiausius procesus, vykstančius žmogaus organizme, jo gyvenime bei globalioje visiems bendroje aplinkoje. Sveikatos priežiūros dokumentai ir jų kūrimas turi daugeli ypatumų [19]:

- atspindi įvairius žmogaus, kaip biologinio ir socialinio organizmo lygius;

- mobili informacija apie mobilų pacientą;

1 lentelè. Medicinos dokumentų apyvarta

\begin{tabular}{|c|c|c|c|c|c|c|c|c|}
\hline \multirow{2}{*}{ Metai } & \multicolumn{2}{|c|}{2009} & \multicolumn{2}{|c|}{2014} & \multicolumn{2}{|c|}{2019} & \multicolumn{2}{|c|}{ Iš viso } \\
\hline & abs.sk. & proc. & abs.sk. & proc. & abs.sk. & proc. & abs.sk. & proc. \\
\hline $\begin{array}{l}\text { Gydymo stacionare } \\
\text { ligos istorija } \\
\text { Nëštumo ir gim- } \\
\text { dymo istorija }\end{array}$ & 48643 & 36,3 & 44399 & 33,1 & 41114 & 30,6 & 134156 & 100 \\
\hline $\begin{array}{l}\text { Medicinių doku- } \\
\text { mentų išrašas/ } \\
\text { siuntimas } \\
\text { (epikrizè) }\end{array}$ & 48643 & 36,3 & 44399 & 33,1 & 41114 & 30,6 & 134156 & 100 \\
\hline $\begin{array}{l}\text { Ambulatorine } \\
\text { asmens sveikatos } \\
\text { istorija (ambulatori- } \\
\text { niai apsilankymai) }\end{array}$ & 163837 & 28,5 & 161543 & 28,1 & 250100 & 43,5 & 575480 & 100 \\
\hline $\begin{array}{l}\text { Laboratoriniai } \\
\text { tyrimai }\end{array}$ & 522026 & 29,8 & 566962 & 32,4 & 659865 & 37,7 & 1748853 & 100 \\
\hline Patologiniai tyrimai & 85490 & 36,8 & 77543 & 33,4 & 69066 & 29,8 & 232099 & 100 \\
\hline Funkciniai tyrimai & 23654 & 26,7 & 30474 & 34,4 & 34530 & 38,9 & 88658 & 100 \\
\hline $\begin{array}{l}\text { Radiologiniai } \\
\text { tyrimai }\end{array}$ & 48289 & 23,9 & 72416 & 35,8 & 81751 & 40,3 & 20456 & 100 \\
\hline Klinikiniai tyrimai & 8400 & 30,9 & 9600 & 32,7 & 11400 & 38,7 & 29400 & 100 \\
\hline Operacijų protokolai & 26535 & 28,6 & 27036 & 31,5 & 32182 & 37,6 & 85753 & 100 \\
\hline Iš viso & 975517 & 30,2 & 1034372 & 32 & 1221122 & 37,8 & 3231011 & 100 \\
\hline
\end{tabular}

2 lentelè. Vadybos dokumentų apyvarta

\begin{tabular}{|l|l|l|l|l|l|l|l|l|}
\hline \multirow{2}{*}{$\begin{array}{l}\text { Moku- } \\
\text { Dotai }\end{array}$} & \multicolumn{2}{c|}{2009} & \multicolumn{2}{c|}{2014} & \multicolumn{2}{c|}{2019} & \multicolumn{2}{c|}{ Iš viso } \\
\cline { 2 - 9 } & abs.sk. & proc. & abs.sk. & proc. & abs.sk. & proc. & abs.sk. & proc. \\
\hline Isakymai & 1832 & 26 & 2347 & 33,3 & 2871 & 40,7 & 7050 & 100 \\
\hline Darbo grafikai & 220 & 31,8 & 228 & 32,9 & 244 & 35,3 & 692 & 100 \\
\hline Tvarkos, protokolai & 33 & 37,9 & 23 & 26,4 & 31 & 35,7 & 87 & 100 \\
\hline Siunčiamieji raštai & 6742 & 41,2 & 5574 & 34,0 & 4064 & 24,8 & 16380 & 100 \\
\hline Gaunamieji raštai & 4738 & 35,9 & 4591 & 34,8 & 3856 & 29,3 & 13182 & 100 \\
\hline Personalo dokumentai & 7176 & 15,2 & 15440 & 32,7 & 24659 & 52,1 & 47275 & 100 \\
\hline $\begin{array}{l}\text { Kokybės vadybos proce- } \\
\text { dūros ir kiti dokumentai }\end{array}$ & 78 & 33,1 & 66 & 28 & 92 & 28,9 & 236 & 100 \\
\hline Audito dokumentai & 60 & 30,8 & 80 & 41 & 55 & 28,2 & 195 & 100 \\
\hline Iš viso & 20879 & 24,5 & 28349 & 33,3 & 35869 & 42,2 & 85097 & 100 \\
\hline
\end{tabular}

- ilgas informacijos saugojimas (pvz., iki 100 metų);

- ịvairūs informacijos nešèjai;

- nuolat kintančios technologijos;

- kintanti terminija bei klinikinis požiūris, įrodomoji bazè, diagnozès ir kt.;

- nuolat kintanti teisine dokumentų kūrimo ir jų saugojimo bei naudojimo bazè.

Dokumentų egzistencija prasideda nuo jų kūrimo, toliau - jų sklaida ir naudojimas, priežiūra ir aptarimas, atšaukimas ir sunaikinimas. Turint galvoje aukštą sveikatos priežiūros dokumentų konfidencialumo lygi, svarbus jų sunaikinimo etapas.

Dokumentai gali būti sunaikinami tokiais būdais:

- kompiuterizuoti dokumentai negrịžtamai ištrinami;

- popieriniai dokumentai sudeginami, susmulkinami, paverčiami minkšta mase, sutrinami;

- mikrofilmai, diskai ir mikrodiskai naikinami kaip popieriniai, kartais dar naudojamas mechaninis poveikis;

- magnetiniai įrašai išmagnetinami.

Tvarkinga ir tiksli dokumentų apyvarta ne tik atspindi sveikatos priežiūros kokybę, bet ir apsaugo medikus nuo įvairių teisinių padarinių, esant pacientų skundams [20,21]. Kartais gydytojai skundžiasi, kad jie sugaišta labai daug laiko, pildydami ar kurdami dokumentus, darydami įrašus, tačiau jie gali daug daugiau laiko sugaišti teisésaugos institucijose bei teismuose, jeigu tų dokumentų nebus ar jie bus netinkamai parengti.

Dokumentų apyvarta, jų apimtys kasmet auga, kai kurių autorių duomenimis, per 30 proc. per metus [22]. Apibendrinant galima teigti, kad dokumentų (popierinių ir elektroninių) pildymas, jų apyvarta, srautų valdymas, saugojimas yra labai svarbi 
sveikatos priežiūros organizacijos veiklos dalis, o darbas su dokumentais - svarbi kiekvieno darbuotojo darbo dalis.

Klaipėdos universitetinès ligoninès popierinių dokumentų apyvartos pokyčiai 2009, 2014, 2019 metais. Per dešimtị metų Klaipedos universitetinès ligoninès dokumentacijos srautai išaugo daugiau nei du kartus ir $2019 \mathrm{~m}$. cirkuliavo apie 1,6 mln. dokumentų. Taip yra iš dalies dèl to, kad dèl ìvairių teisinių niuansų elektroniniai dokumentai dubliuojami su popieriniais. Nors literatūroje yra duomenų, kad popierinių dokumentų era ligoninèse baigiasi $[4,22]$, praktikoje viskas keičiasi ne taip greitai. Popierinių dokumentų kiekis, cirkuliuojantis ligonineje per tirtus metus, siekia per 1,5 milijono. Dokumentai tarnauja kaip irodymas, patvirtinimas konkretaus įvykio, fakto ar sandorio, todèl reikšminga jų įforminimo visuma ir kokybè, nes tai užtikrina jų juridinę galią. Be to, dauguma instituciju (teisinių, politinių, finansinių ir kt.), kaip ir medikai, kol kas labiau pasitiki popieriniais dokumentais. Panaši situacija ir kitose šalyse [11].

Medicinos dokumentų apyvarta yra pati didžiausia ir jų kiekis kasmet didejjo (1 lentelè). Vykdant šalies sveikatos politiką, stacionarizuotų pacientų skaičius mažèjo, didejjant ambulatorinių pacientų skaičiui. Analogiškai keitèsi ir medicinos dokumentų srautai. Būtina pažymèti, kad paciento gydymo stacionare ligos istorija yra labai imlus ir platus dokumentas, šių istorijų pildymo apimtis taip pat didejo. Mažejo tik patologinių tyrimų dokumentų apimtis.

Kitų dokumentų kiekiai analizuojamais metais statistiškai patikimai didèjo.

Pateiktoje lenteleje neatspindèta išrašomų popierinių receptų ir nedarbingumo pažymèjimų apyvarta. Receptų $2009 \mathrm{~m}$. buvo išrašyta apie 180 tūkst., $2014 \mathrm{~m}$. apie 110 tūkst., 2019 m. apie 60 tūkstančių. Vis daugiau išrašoma e. receptu, mažèja popierinių. Pastebeta, kad tam tikra dalis popierinių receptų išrašoma beveik visose šalyse, dažniausia priežastis - pacientų duomenų apsauga. Žinant išrašytą vaistą, galima atpažinti ligos diagnozę, pavyzdžiui psichi- kos ligą, vėžį ar kt., todèl popierinis receptas šiuo atžvilgiu yra saugesnis pacientui. Pacientui turètų būti teikiama galimybè pasirinkti elektroninị arba popierinị receptą.

Kasmet ligoninèje išrašoma per 10 tūkst. nedarbingumo pažymejjimų, pastaraisiais metais tik elektroniniai, popierinių praktiškai nëra. Dar kasmet išrašoma apie 500 ịvairių popierinių pažymų.

Vadybos dokumentų kiekis ligonineje analizuojamais metais statistiškai patikimai didejjo (2 lentelè). Statistiškai patikimai didejo personalo dokumentų bei ịsakymų ir potvarkių skaičius, kurị lèmé didejjantis ịvairių institucijų, tarp jų ir teisinių, veiklos reikalavimų reglamentavimas. Mažèjo siunčiamų ir gaunamų raštų skaičius, nes susirašinèjimas laipsniškai persikelia ị elektroninę erdvę.

Daugelis autorių pažymi medicinos ir vadybos dokumentų svarbą ịvairiomis krizinemis situacijomis. COVID - 19 pandemijos ir karantino metu dokumentuose registruojami ịvairūs faktai, kurie vèliau gali būti reikalingi teisinèms ar kontroliuojančioms institucijoms. Šie dokumentai gali būti labai

3 lentelė. Finansiniu dokumentų apyvarta

\begin{tabular}{|l|c|c|c|c|c|c|c|c|}
\hline \multirow{2}{*}{$\begin{array}{l}\text { Doku- Metai } \\
\text { mentai }\end{array}$} & \multicolumn{2}{|c|}{2009} & \multicolumn{2}{c|}{$\mathbf{2 0 1 4}$} & \multicolumn{2}{c|}{$\mathbf{2 0 1 9}$} & \multicolumn{2}{c|}{ Iš viso } \\
\cline { 2 - 9 } & abs.sk. & proc. & abs.sk. & proc. & abs.sk. & proc. & abs.sk. & proc. \\
\hline Sąskaitos & 10942 & 31,9 & 10627 & 31,0 & 12725 & 37,1 & 34294 & 100 \\
\hline Pavedimai & 3662 & 30,6 & 4173 & 34,9 & 4136 & 34,5 & 11971 & 100 \\
\hline $\begin{array}{l}\text { Kiti finansiniai } \\
\text { dokumentai }\end{array}$ & 7892 & 32,2 & 8497 & 34,6 & 8149 & 33,2 & 24538 & 100 \\
\hline Iš viso & 22496 & 31,8 & 23297 & 32,9 & 25010 & 35,3 & 70803 & 100 \\
\hline
\end{tabular}

4 lentelè. İvairių dokumentų apyvarta

\begin{tabular}{|c|c|c|c|c|c|c|c|c|}
\hline \multirow{2}{*}{$\begin{array}{l}\text { Moku- } \\
\text { mentai }\end{array}$} & \multicolumn{2}{|c|}{2009} & \multicolumn{2}{|c|}{2014} & \multicolumn{2}{|c|}{2019} & \multicolumn{2}{|c|}{ Iš viso } \\
\hline & abs.sk. & proc. & abs.sk. & proc. & abs.sk. & proc. & abs.sk. & proc. \\
\hline $\begin{array}{l}\text { Patariamujų } \\
\text { valdymo } \\
\text { organų doku- } \\
\text { mentai }\end{array}$ & 17 & 27 & 20 & 31,7 & 26 & 51,3 & 63 & 100 \\
\hline $\begin{array}{l}\text { Pirkimų doku- } \\
\text { mentai }\end{array}$ & 1220 & 12,3 & 4655 & 46,8 & 4064 & 40,9 & 9939 & 100 \\
\hline $\begin{array}{l}\text { Pacientu ir per- } \\
\text { sonalo } \\
\text { apklausos }\end{array}$ & 47900 & 36,3 & 43570 & 33,0 & 40443 & 30,7 & 131913 & 100 \\
\hline $\begin{array}{l}\text { Sandėlių doku- } \\
\text { mentai }\end{array}$ & 14348 & 34,8 & 13868 & 33,7 & 12989 & 31,5 & 41205 & 100 \\
\hline $\begin{array}{l}\text { Archyvo doku- } \\
\text { mentai }\end{array}$ & 425318 & 35,1 & 462914 & 38,2 & 325096 & 26,7 & 1213328 & 100 \\
\hline $\begin{array}{l}\text { Ivvairūs žurnalai } \\
\text { skyriuose }\end{array}$ & 11 & 21,2 & 22 & 42,3 & 19 & 36,5 & 52 & 100 \\
\hline $\begin{array}{l}\text { Identifikavimo } \\
\text { dokumentai }\end{array}$ & 3436 & 34,5 & 3322 & 33,3 & 3210 & 32,2 & 9968 & 100 \\
\hline Kiti dokumentai & 210 & 32,8 & 220 & 34,4 & 210 & 32,8 & 640 & 100 \\
\hline Iš viso & 492460 & 35 & 528591 & 37,6 & 386057 & 27,4 & 1407108 & 100 \\
\hline
\end{tabular}


naudingi kuriant prevencines programas, vakcinas, taikant svarbias profilaktines, priešepidemines priemones, gerinant sveikatos priežiūros kokybę [15-17].

Finansinių dokumentų skaičius kasmet didèjo (3 lentelè). Finansiniai dokumentai atspindi turto būklę, materialiujų vertybių apyvartą, turto nusidèvejjimą, investicijų naudą, todèl jie yra ypač svarbūs.

Kitų ỉvairių dokumentų apyvartos duomenys pateikti 4 lentelèje. Bendras jų skaičius mažèjo. Tai vyko keičiantis archyvinių dokumentų saugojimo terminams, diegiant elektroninius dokumentus ir dèl ịvairių kitų priežasčių.

Apibendrinant galima teigti, kad popierinių dokumentų apyvartos mažinimui būtini sisteminiai sprendimai (pavyzdžiui, dèl ligos istorijų ir kt.). Tokie sprendimai buvo priimti dèl receptų, nedarbingumo pažymėjimų, vairuotojų sveikatos patikrinimo medicininių bei kitu pažymų išrašymo. Visiškai eliminuoti popierinių dokumentų dèl ịvairių priežasčių ESPBI IS trukdžių ir kitų - nepavyks, bent jau artimiausiais metais.

\section{Išvados}

1. Popierinių dokumentų skaičius ir jų apyvarta Klaipėdos universitetinèje ligoninèje yra dideli. Šių dokumentų kiekiams ir apyvartai mažinti būtini sisteminiai sprendimai ir gerai veikianti ESPBI informacinè sistema.

2. Dokumentų (popierinių ir elektroninių) rengimas, jų apyvarta, srautu valdymas, saugojimas yra labai svarbi sveikatos priežiūros organizacijos veiklos dalis. Tiek medicinos, tiek vadybos dokumentai ypač svarbūs, gerinant sveikatos priežiūros kokybę.

\section{Literatūra}

1. Geissbuhler A, Haux R, Kulikowski C, et al. Biomedical informatics for sustainable health care. IMIA yearbook of medical informatics. Stuttgart: Schatauer GmbH 2007.

https://doi.org/10.1055/s-0038-1638519

2. Janušonis V. Sveikatos apsaugos sistemos organizacijų valdymas. Klaipėda: S.Jokužio leidykla-spaustuvè, 2012.

3. Waegemann CP, Tessier C, Barbash A, et al. Healthcare documentation: a report on information capture and report generation. newton. MA: Medical Records Institute 2002.

4. Healthcare informatics. The changing role of paper in healtcare. 2016. http://www.informationweek.com

5. Kneck A, Flink M, Frykholm O, et al. Information flow in a healthcare organisation with integrated units. International Journal of Integrated Care 2019:20-47. https://doi.org/10.5334/ijic.4192

6. Nissinboim N, Naveh E. Process standardization and error reduction: a revisit from a choice approach. Safety Science 2017; 103:43-50. https://doi.org/10.1016/j.ssci.2017.11.015

7. Brown PJ, Marquard JL, Amster B, et al. What do physicians read (and ignore) in electronic progress notes? Applied Clinical Informatics 2014;5(2): 430-444.

https://doi.org/10.4338/ACI-2014-01-RA-0003

8. Evans RS. Electronic health records: then, now, and in the future. Yearb of Medical Informatics 2016;Suppl 1:S48-S61.

https://doi.org/10.15265/IYS-2016-s006

9. Hahn JS, Bernstein JA, McKenzie RE, et al. Rapid implementation of inpatient electronic physician documentation at an academic hospital. Applied Clinical Informatics 2012;3:175-185. https://doi.org/10.4338/ACI-2012-02-CR-0003

10. Edwards ST, Neri PM, Volk LA, et al. Association of note quality and quality of care: a cross-sectional study. BMJ Quality and Safety 2014;23:406-413.

https://doi.org/10.1136/bmjqs-2013-002194

11. Healtcare informatics 2020. http://www.informationweek. com/healtcare.

12. ASHA. Documentation in health care. American Speech-Language-Hearing Association (ASHA) 2020. https://www.asha.org.

13. González-Ortiz LG, Calciolari S, Goodwin N, et al. The core dimensions of integrated care: a literature review to support the development of a comprehensive framework for implementing integrated care. International Journal of Integrated Care 2018;18:10-24.

https://doi.org/10.5334/ijic.4198

14. Zonneveld N, Driessen N, Stüssgen RAJ, Minkman MMN. Values of integrated care: a systematic review. International Journal of Integrated Care 2018;18:4-14.

https://doi.org/10.5334/ijic.4172

15. Russell RS, Johnson DM, White SW. Patient perceptions of quality: analyzing patient satisfaction surveys. International Journal of Operations and Production Management 2015;35:1158-1181. https://doi.org/10.1108/IJOPM-02-2014-0074

16. Janušonis V. Organizacinè elgsena ir kokybè sveikatos priežiūroje. Integracinė sisteminè apžvalga. Klaipèda: S. Jokužio leidykla-spaustuvè, 2017.

17. Olsen BJ, Lund NW, Bellika JG, et.al. Documents in medicine: from paper documents to quality-healthcare? 2020. http://www. munin.unit.no/bitstream/handle.com/healtcare

18. Janušonis V. Rizikos valdymas sveikatos priežiūros organizacijose. Sisteminė teorinė - praktinė apžvalga. Klaipėda: S. Jokužio leidykla-spaustuvè, 2016.

19. Haux R. Medical informatics: past, present, future. International Journal of Medical Informatics 2010;79:599-610.

https://doi.org/10.1016/j.ijmedinf.2010.06.003

20 . Austin S. Stay out of court with proper documentation. Nursing 2011;41:24-29. https://doi.org/10.1097/01.NURSE.0000395202.86451.d4

21. Jefferies D, Johnson M, Griffiths R. Meta-study of the essentials of quality nursing documentation. International Journal of 


\section{6}

Nursing Practice 2010;16:112-124.

https://doi.org/10.1111/j.1440-172X.2009.01815.x

22. Rowe N. Handling paper in a digital age - the impact of document management. Aberdeen. 2012.

\section{CHANGES IN DOCUMENTS CIRCULATION IN A HEALTH CARE ORGANIZATION: CASE STUDY G. Kasap, V. Janušonis}

Keywords: documents circulation, information, documents flows, documents management.

Summary

Documents are very important in a health care organization as a source and carrier of information. They affect health care quality.

The aim of the study - to review the circulation of documents in health care organization in various countries and to determine the flows of paper documents and their changes in 2009-2014-2019 in Klaipeda University hospital.

Methods - retrospective statistical and comparative analysis of document circulation, analysis of literature, data synthesis and generalization.

Results. There are four types of documents circulating in the health care organization: medical, managerial, financial, and various.

About 1,5 million documents are curculating in the Klaipeda University hospital each year, and the number is growing in all groups analyzed.

Conlusions. The number of paper documents and their circulation in the Klaipeda University hospital is high. Reducing the volume and turnover of these documents requires systemic sulutions and a well - funkctioning information system in the country.

Document preparation, circulation, flow management, and storage is a very important part of the health care organization activities - both medical and managerial documents are especially important in improving health care quality.

Correspondence to: gaivile@inbox.lt

Gauta 2020-11-26 